\title{
Distribution Patterns of Grasshoppers and Their Kin in the Boreal Zone
}

\author{
Michael G. Sergeev ${ }^{1,2}$ \\ ${ }^{1}$ Department of General Biology and Ecology, Novosibirsk State University, 2 Pirogova Street, Novosibirsk 630090, Russia \\ ${ }^{2}$ Laboratory of Insect Ecology, Institute of Systematics and Ecology of Animals, Siberian Branch, Russian Academy of Sciences, \\ 11 Frunze Street, Novosibirsk 630091, Russia
}

Correspondence should be addressed to Michael G. Sergeev, mgs@fen.nsu.ru

Received 1 August 2010; Accepted 17 September 2010

Academic Editor: Alexandre Latchininsky

Copyright () 2011 Michael G. Sergeev. This is an open access article distributed under the Creative Commons Attribution License, which permits unrestricted use, distribution, and reproduction in any medium, provided the original work is properly cited.

The distribution patterns of Orthoptera are described for the boreal zone. The boreal fauna of Eurasia includes more than 81 species. Many of them are widely distributed. The monotypic genus Paracyphoderris Storozhenko and at least 13 species are endemics or subendemics. About 50 species are known from boreal North America. Four endemic species are distributed very locally. Relationships between the faunas of the Eurasian and North American parts of the boreal zone are relatively weak. The boreal assemblages are usually characterized by the low levels of species diversity and abundance. Grasshoppers and their relatives occupy almost exclusively open habitats, such as different types of meadows, mountain steppes and tundras, clearings, openings, bogs, and stony flood plains. The local endemics and subendemics are found only in some habitats of the eastern part of Eurasia and the north-western part of North America. Retrospective and prospective of the boreal fauna of Orthoptera are also discussed.

\section{Introduction}

The boreal zone is the huge area in the Northern Hemisphere where the coniferous forests form the main type of vegetation [1], average temperatures are relatively low (mean temperatures of the warmest month vary from $6.5^{\circ} \mathrm{C}$ to $19^{\circ} \mathrm{C}$, the same for the coldest month, from $-6^{\circ} \mathrm{C}$ to $-49^{\circ} \mathrm{C}$ ), and annual precipitation varies from relatively high near Atlantic and Pacific oceans (more than $1600 \mathrm{~mm}$ per year) to very low in the inner parts of the continents (less than $200 \mathrm{~mm}$ ) [2]. From the ecogeographic point of view, in Eurasia, this life zone almost corresponds with the so-called taiga area $[1,2]$. In North America, it occupies the significant part of the so-called SpruceCaribou Biome [3] and almost corresponds to the united boreal life zone sensu Merriam [4]. From the zoogeographic point of view, in Eurasia, the boreal zone almost coincides with the Eurosiberian Region (or Subregion) (without the Subarctic and Arctic areas) erected mainly on the basis of the species distribution analysis [5-8]. In North America, it more or less coincides with the so-called Canadian Region [5].
The climatic conditions and dominated coniferous forest habitats are not comfortable for most grasshoppers and their relatives. The general level of their diversity is relatively low [7, 9-12]. Ecological peculiarities and adaptations of most species associated with the boreal zone are almost unknown $[9,11]$. There are no species inhabiting coniferous trees and shrubs. Almost all forms prefer openings with herbaceous vegetation and meadows. Several species (mainly from the tribe Melanoplini and some widely distributed katydids) usually settle shrubs along forest edges $[9,13,14]$. A few forms prefer herbaceous microhabitats under a coniferous forest canopy. Among them are Podismopsis silvestris Storozh. [15] and, in some parts of its range, Prumna primnoa (F.d.W.) (our unpublished data). Many species are univoltine with overwintering eggs, but in North America several forms are semivoltine: they pass the first cold season as eggs and the second as hoppers [16]. Their development is limited by a relatively short warm season. This results in more or less simultaneous development of almost all species [13]. Besides that, many local grasshoppers prefer to lay egg pods on leaves, in leaf axils, grass stems, rotten woods, leaf litter, and in the upper soil layer $[11,13,14,17]$. 
Uvarov [13] emphasized that the boreal area can be regarded as devoid of grasshoppers. However, there are different types of meadows, openings, and bogs that can be settled by some species. Beside that, mountains are well developed in different parts of the boreal zone, especially in the eastern part of Eurasia and in the western part of North America. A complicated relief of the mountain systems provides a level of landscape diversity comfortable for many grasshoppers and their kin. There are many dry and warm habitats with steppe-like vegetation, especially along southern slopes of ridges, and alpine and subalpine meadows, often with shrubs, above the timberline. As a result, the boreal zone is populated by both endemic taxa and extremely abundant species which can form outbreaks during droughts. The main aim of this paper is to establish general patterns of Orthoptera distribution in the boreal zone.

\section{Methods and Materials}

Both qualitative and quantitative data were used. The analysis of geographic distribution was based on published and unpublished species range maps. Species data points for Eurasian Orthoptera were plotted onto base maps, usually on a scale of $1: 25,000,000$. My own collections, the collections of different museums, and published data were used [6, 7]. Besides, several maps published by Albrecht [18] for Fennoscandia were adopted. I also analyzed the published species range maps of North American Orthoptera [10, 11, $16,19,20]$.

The analysis of ecological distribution was based on quantitative samples collected in natural and seminatural habitats. Samples captured during a fixed period of time were made in every habitat investigated $[6,21]$. Using this method, insects were caught with a standard net over a period of 10-30 minutes. Results for every habitat were recalculated for an hour. This method allowed us to obtain repeatable and comparable results for different regions and years. These samples were collected in some parts of the Eurasian boreal zone by the expeditions of the Department of General Biology and Ecology (Novosibirsk State University) and the Laboratory of Insect Ecology (Institute of Systematics and Ecology of Animals) from 1972 to 2003. Several published papers [14, 15, 22-28] describing orthopteran assemblages in different parts of the boreal zone were also used.

\section{Geographic Distribution}

The general distribution of grasshoppers and their kin in the Holarctic Region reflects the southern thermophilic character of these insects and their common association with open habitats, such as different grasslands, openings, bogs, and so forth [7, 11-13]. Grasshoppers are not typical of the tundra life zone $[16,29,30]$ although a few species occur in the southern tundra and forest tundra. The only species penetrating in the northern tundra of North America is Aeropedellus arcticus Heb. [19]. The most common grasshopper of the tundra as a whole is Melanoplus frigidus
(Boh.). The fauna of the boreal life zone includes about 130 species of Orthoptera. Many of them are distributed only in its southern part. Hundreds of species are found southwards, in the nemoral (broad-leaf) forest, steppe, and prairie life zones [7].

Bey-Bienko [9] analyzed the general distribution patterns of Orthoptera in the boreal zone of the former USSR. He noted occurrence of 31 species in its western part and 44 in the eastern one (51 species in total). Prevalence of species preferring grass layers of local ecosystems was also emphasized. Bey-Bienko described some differences between orthopteran distribution patterns in the western (where dark coniferous forests dominate) and eastern (mainly with light coniferous forests) taiga. In the western part, grasshoppers usually settle openings and bogs. In the eastern part, local species settle both the same set of habitats as in the western taiga and more or less dry plots (steppes, dry meadows), but often on the higher level of abundance. They also can survive winters with very low temperatures.

The fauna of the boreal part of Eurasia includes more than 81 species of Orthoptera, about 3/4 of them are the members of the family Acrididae. Many species are widely distributed in the boreal zone of Eurasia, usually from Atlantic Ocean to the Pacific one (Figures 1 and 2). Among them are Podisma pedestris (L.), Melanoplus frigidus, Aeropus sibiricus (L.), Aeropedellus variegatus (F.d.W.), Stethophyma grossum (L.), Bryodema tuberculatum (F.), Chrysochraon dispar (Germ.), Omocestus haemorrhoidalis (Charp.), $O$. viridulus (L.), Chorthippus montanus (Charp.), Ch. albomarginatus (Deg.), Metrioptera brachyptera (L.), Decticus verrucivorus (L.), Tetrix subulata (L.), and T. fuliginosa (Zett.). Besides, there are many species which populate either the western (European) part of the zone (Chorthippus pullus (Phil.), Oedipoda caerulescens (L.), Sphingonotus caerulans (L.), Tetrix undulata (Sow.), and Pholidoptera griseoaptera (Deg.)), or the southern Siberian Mts. (Montana tomini (Pyln.), Stenobothrus eurasius Zub., and Bryodema holdereri Kr.), or its eastern part (Zubovskya koeppeni (Zub.), Chorthippus fallax (Zub.), Sphagniana ussuriana (Uv.), and Tetrix japonica (I. Bol.)) (Figures 1-3). They often occur in the northern parts of the taiga and, in some cases, penetrate in the tundra, especially either in the European or Beringian ones. The sparse local populations of the Migratory locust (Locusta migratoria L.) are also found in the European taiga area [18]. Almost all widely distributed species are associated with either the subboreal areas (especially with the foreststeppes, steppes and semideserts in the inner territories of Eurasia) or the deciduous forest life zone of Europe or the Far East. In the boreal zone, they often settle very dry habitats, for example, openings in pine forests on sandy soils. Some widely distributed grasshoppers (e.g., Aeropus sibiricus, Melanoplus frigidus, and Podisma pedestris) have isolated populations in the mountains of south temperate Eurasia (from Pyrenees to Central Asia) (Figure 2) [31, 32].

The genus Paracyphoderris Storozhenko (with one species-P. erebeus Storozhenko) (Figure 1) and at least 13 species are endemics or subendemics of the boreal zone of Eurasia. All of them are distributed only in its eastern part. Some endemic species have relatively broad ranges 


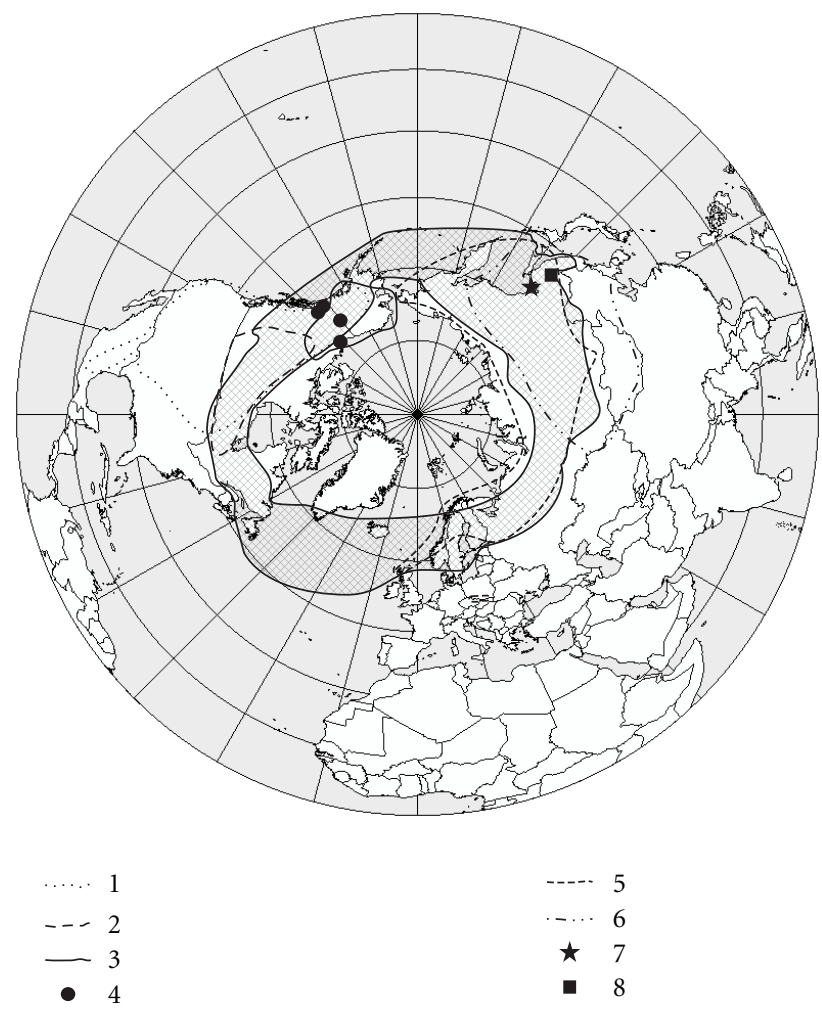

Figure 1: Distribution of Arphia conspersa (1), Sphagniana sphagnorum (2), Aeropodellus arcticus (3), Xanthippus brooksi (4), Tetrix fuliginosa (5), Chorthippus fallax (6), Ch. shantariensis (7), and Paracyphoderris erebeus (8) relative to the boreal zone (crosshatching) (see text and references for details). The boundaries of the boreal zone based on $[1,2,5]$ with some minor changes and simplification. The basic map is "Northern Hemisphere of Earth (Lambert Azimuthal projection)" by Sean Baker from http://commons.wikimedia.org/wiki/file:Northern_Hemi- sphere_LamAz.png, under the CC-by-2.0 license.

(usually from the Enisej River basin to Pacific ocean): Prumna polaris Mir., Zubovskya koeppeni, Podismopsis jacuta Mir., and P. gelida Mir. (Figures 2 and 3). Their local populations can be usually found in the mountains of South Siberia and Mongolia and in the southern tundra of northeastern Siberia. The others are distributed locally (Prumna specialis (Mistsh.), P. arctica (Zhang et Jin), P. montana (Storozhenko), Chrysochraon amurensis Mistsh., Podismopsis silvestris, $P$. insularis Mistsh., Chorthippus shantariensis Mistsh., and Paracyphoderris erebeus) (Figures 1-3). Among them are both insular (Podismopsis silvestris-Sakhalin, $P$. insularis and Chorthippus shantariensis-Shantar Islands) and montane endemics (Prumna specialis, P. montanaSihote-Alin, and $P$. arctica-Greater Khingan). It is interesting that the majority of endemics are from two acridid tribes: Melanoplini (Figure 2) and Chrysochraontini (Figure 3). Besides, in the southern part of the Russian Far East, there are two montane endemics, namely, Hypsopedes kurentzovi B.-Bienko and Prumna kurentzovi (Mistsh.), which have populations outside the boundaries of the boreal zone, but above the timberline. All endemics have relatively short or no wings. Hence, their possibility to migrate is very limited.

Thus, in the boreal zone of Eurasia, the main area of diversity and endemism of Orthoptera is in the eastern
(Pacific) part. Its endemics are mainly close relatives of forms associated with the Manchurian Subregion [7].

The general patterns of Orthoptera distribution in North America were described by Vickery [10] and Kevan [33]. Both authors noted that there are several widely distributed species, mainly from Acrididae and Tetrigidae. Vickery [10] emphasized that only a few species are found in the tundra of this continent. More than 50 species are known from the boreal zone of North America [10, 11, 19, 20, 34]. About $57 \%$ are members of the family Acrididae. There are at least 5 species of crickets (both Gryllinae and Nemobiinae). Another specific feature is presence of several species of the genus Melanoplus Stål.

Many species are widely distributed in the boreal zone of North America, usually from Pacific Ocean to the Atlantic one. Among them are Stethophyma gracile (Scudd.), S. lineatum (Scudd.), Chloealtis conspersa (Harris), Ch. abdominalis (Thomas), Chorthippus curtipennis (Harris), Pardalophora apiculata (Harris), Camnula pellucida (Scudd.), Trimerotropis verruculata (Kirby), Melanoplus borealis (Fieb.), M. fasciatus (F. Walk.), M. sangunipes (Fabr.), and Tetrix subulata (L.) (Figures 2 and 3). They often occur in the northern parts of the taiga and, in some cases, penetrate in the tundra. Aeropedellus articus is almost 


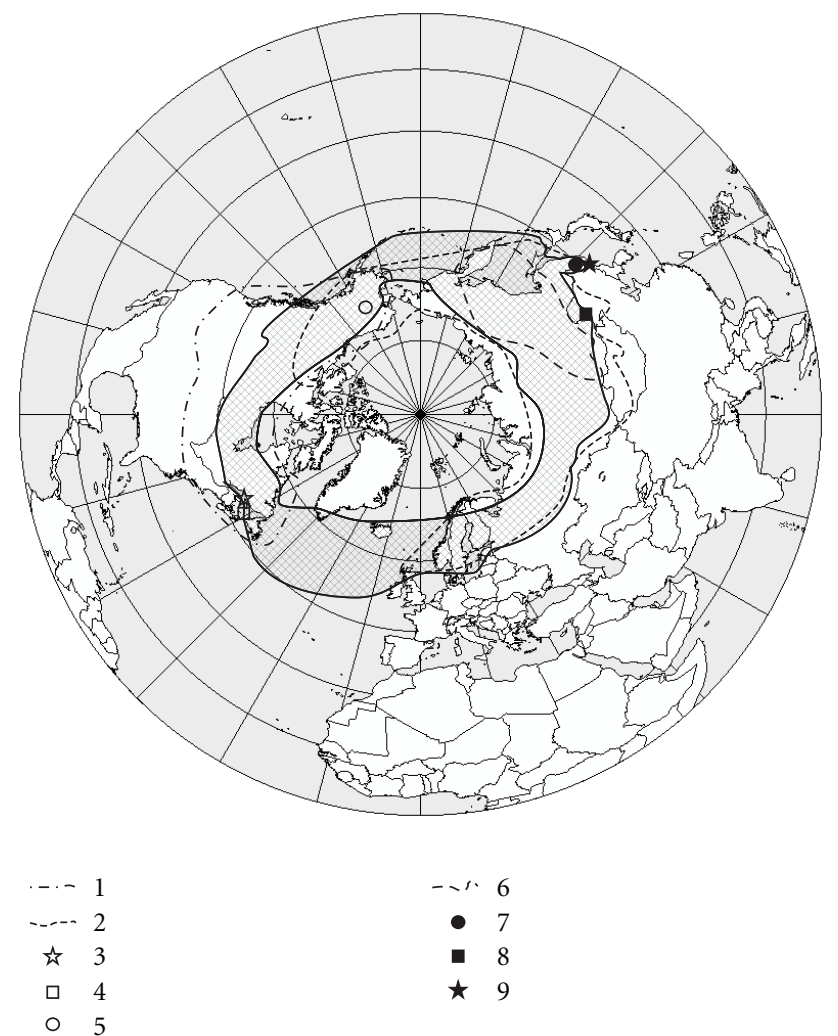

FIgURE 2: Distribution of the Melanoplini grasshoppers: Melanoplus borealis (1), M. firgidus (2), M. gaspesiensis (3), M. madeleineae (4), M. gordonae (5), Prumna polaris (6), P. specialis and P. montana (7), P. arctica (8), and P. kurentzovi (9) relative to the boreal zone.

unique grasshoppers penetrating in the northern tundra of north-western North America (Figure 1). Almost all widely distributed species are associated either with the subboreal areas, especially with the prairies and forest-prairies in the inner territories of North America, or with the mixed and deciduous forest areas of the Atlantic coast (Figures 2 and 3). Besides, there are several species which occupy the western part of the zone (Arphia conspersa Scudd. and Encoptolophus costalis Scudd.) (Figure 1).

Two North American species may be characterized as subendemics of the boreal zone with relatively broad ranges. Aeropedellus arcticus is distributed in the north-western part of the continent (Figure 1). This grasshopper prefers different tundra habitats [16]. The second species is the katydid Sphagniana sphagnorum (F. Walk.) which occurs in the central part of the boreal life zone. The main part of the range of Xanthippus brooksi Vickery (Figure 1) is in the western part of the boreal zone, but the local population is found near the delta of the Mackenzie River, outside this zone $[10,16]$. Four endemic species are distributed very locally. Melanoplus gordonae Vickery is found in the vicinities of Fairbanks (Alaska) (Figure 2). Bruneria yukonensis Vickery is distributed in the southern part of Yukon [16, 28]. Melanoplus gaspesiensis Vickery and M. madeleineae Vickery and Kevan are limited by the small territories on the Atlantic coast (Figure 2). The latter occupies the Magdalen Islands. Both species are close to M. borealis [35]. Unlike the endemics of boreal Eurasia, the North American have either short or well developed wings (Xanthippus brooksi and Melanoplus gordonae).

Thus, in the boreal zone of North America, the two very weak regions of Orthoptera endemism are in the western and eastern parts. Their relatives are quite different from the zoogeographic and taxonomic points of view and occur in boreal and subboreal Eurasia (Sphagniana sphagnorum and Aeropedellus arcticus), in the Great Plains and the Rocky Mountains (Xanthippus brooksi and Bruneria yukonensis), and in the temperate areas of North America (Melanoplus gordonae). Compared to the fauna of the boreal Eurasia, the local fauna of Orthoptera looks like impoverished. The main reasons of this distinction can be significant difference both in the areas occupied by the boreal zone in North America and Eurasia (correspondingly about $5.4 \times 10^{6}$ and $8.4 \times 10^{6} \mathrm{~km}^{2}$, based on soil distribution patterns [36]) and in the Pleistocene history of the regions. For instance, during the last glacial maximum, the northern half of North America was covered by the ice sheet (except some areas in Beringia) [37]. On the contrary, in Eurasia, the Asian part was almost free from plain ice sheets, but relatively small ice sheets developed in mountains and in the north-western part. These reasons do not exclude one another.

Relationships between the orthopteran faunas of the Eurasian and North American parts of the boreal zone are relatively weak, but they are more significant than for the whole Palaearctic and the whole Nearctic Regions. There are only two common species: Tetrix subulata and 
Melanoplus frigidus (except invasive forms, such as Roeseliana roeselii (Hagen.)). Moreover, Melanoplus frigidus occurs only in the north-western part of North America. Several North American species have close relatives in Eurasia: Chorthippus curtipennis is the member of the Chorthippus parallelus group, and Aeropedellus arcticus is similar to Ae. variegatus. Besides, there are some common genera. However, these genera can be divided into two groups: the first includes genera distributed mainly in the Holarctic area (Stethophyma Fisch., Sphagniana Zeun., and Melanoplus Stål), and the second one includes genera (Conocephalus, Gryllus, Tetrix) widely distributed in both the temperate and tropical regions. Relationships between genera (e.g., Bruneria-Stenobothrus, Chloealtis Harris-Chrysochraon Fisch., Ageneotettix McNeil-Dociostaurus Fieb.) are not so evident and should be discussed after taxonomic revisions of these groups.

\section{Ecological Distribution}

The general pattern of ecological distribution of boreal Orthoptera is relatively simple: they prefer different types of meadows, steppes, edges, openings, river valleys, and bogs. However, the quantitative data concerning ecological distribution and assemblages of these insects in the boreal zone are extremely limited. There are several publications for different parts of Eurasia and only one paper for North America.

Bey-Bienko [22] was the first orthopterist who described assemblages of Orthoptera in the boreal zone, in the eastern part of West Siberian Plain. He noted the low levels of diversity (4-9 species) in all habitats and relatively high levels of abundance of Chorthippus albomarginatus, Glyptobothrus biguttulus (L.), and Aeropus sibiricus at the dry openings of the local pine forests on sandy soils. The main species over the flood plain meadows were Tetrix subulata, Stethophyma grossum, and Chorthippus montanus. Bey-Bienko also emphasized evident localization of all orthopteran populations.

Chernyakhovskiy $[14,25]$ described main parameters for the assemblages of Orthoptera in the middle taiga of European Russia (Pechoro-Ilychskiy State Reserve). The level of species diversity is also low (2-11 species). The maximal numbers of species are found in meadows and clearings. The minimal diversity is in the lower flood plains and bogs. Omocestus viridulus and Chorthippus apricarius (L.) dominate in meadow habitats, whereas Stethophyma grossum is the most abundant form in bogs.

In the southern taiga of West Siberian Plain, the orthopteran assemblages investigated include from 3 to 11 species. The general abundance is relatively low. The maximal numbers of registered species and specimens (up to 676 per hour) are found on the meadow terraces. Metrioptera brachyptera (L.), Chorthippus apricarius (L.), and Glyptobothrus biguttulus are the common dominants on the plain and terraces. Stethophyma grossum is abundant in the assemblage of the wet flood plain meadows. The similar pattern is described by Chernyakhovskiy [24] for the vicinities of Tomsk.
In the middle taiga of Central Siberia, the level of species diversity is similar [23]. The local assemblages usually include several species of grasshoppers. Chorthippus apricarius is common in the plain meadow habitats. Tetrix tenuicornis (Sahlb.) dominates in the bog ecosystems. The maximal number of species (10) is registered on the stony flood-plains. Glyptobothrus brunneus (Thnb.) [? - M.S.], Chrysochraon dispar, Aeropus sibiricus, and Podisma pedestris are abundant here.

The specific, near-polar steppes of north-eastern Yakutia are mainly inhabited by the widely distributed steppe grasshopper [27]. The similar situation is in the dry parts of central Yakutia, in which Chorthippus albomarginatus, Aeropus sibiricus, Glyptobothrus maritimus, and Omocestus haemorrhoidalis are the most common species over all meadow and steppe-like habitats. The local openings are characterized by dominance of Podisma pedestris and Melanoplus frigidus. This part of the boreal zone is very specific due to short, but hot and often dry summer season. After several years with droughts, the general abundance of grasshoppers may increase significantly. As s result, they can damage almost all vegetation [38].

In the middle taiga of south Yakutia, the orthopteran assemblages are relatively diverse and include many species (from 11 to 27) [26]. This pattern may be determined by the rather complicated mosaic of mountain slopes, river valleys, and plateaus. Beside that, this area is near the northern boundary of the Manchurian Subregion of the Palaearctic. As a result, some species associated with the broad-leaf forest life zone penetrate northwards. Podismopsis gelida and Aeropedellus variegatus are the common species in the mountain tundra. Dry slopes are mainly inhabited by Melanoplus frigidus and Gomphocerus rufus (L.). Tetrix fuliginosa, Melanoplus frigidus, Chrysochraon dispar, and Podismopsis poppiusi dominate in the different assemblages in the bog and meadow habitats.

In the boreal part of Sakhalin, Storozhenko [15] found orthopteran assemblages similar to the continental ones. The species number varies from 1 to 9 . The local populations are sparse. The endemic Podismopsis silvestris is the only species inhabiting plots of the spruce forests with green mosses. This grasshopper is found only here. Another endemic distributed in the Pacific part of the boreal zone, namely Aeropus kudia (Caud.), settles all more or less open habitats. Prumna primnoa and Zubovskya koeppeni are dominants on openings. Chorthippus intermedius (B.-Bien.) are the most abundant form in different meadow habitats. Glyptobothrus maritimus (Mistsh.) dominates on the lower flood plains.

Berman et al. [28] described ecological distribution and assemblages of grasshoppers in the habitats of the southern part of Yukon. The levels of species diversity and abundance are very low. The first varies from 2 to 8 and the later from 18 to 61 specimens per hour. Bruneria yukonensis and Melanoplus kennicottii Scudd. dominate in different variants of the sagebrush steppes. M. kennicotti, M. borealis, M. fasciatus (F. Walk.), and Cloealtis abdominalis are the most abundant grasshoppers in the different mountain tundra. The local endemics, namely Bruneria yukonensis and Xanthippus brooksi, are found in 


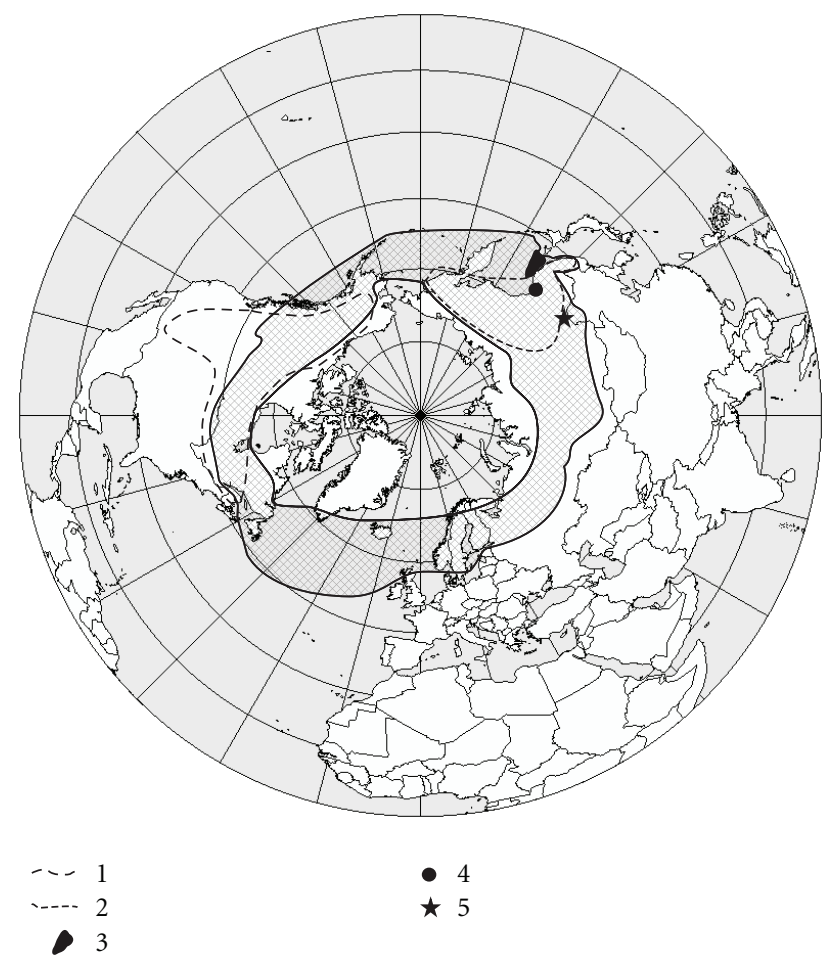

FIgure 3: Distribution of the Chrysochraontini grasshoppers: Chloealtis conspersa (1), Podismopsis gelida (2), P. silvestris (3), P. insularis (4), and Chrysochraon amurensis (5) relative to the boreal zone.

the steppe habitats. The abundance of the first one is relatively high.

Thus, compared to the orthopteran assemblages of the southward territories [39, 40], the assemblages described from the boreal zone are usually characterized by the low levels of species diversity and abundance. In this area, grasshoppers and their relatives occupy almost exclusively open habitats, such as different types of meadows, mountain steppes and tundras, clearings, openings, bogs, and stony flood plains. In the main part of the zone, orthopteran assemblages are composed from widely distributed species usually inhabiting the broad variety of life zones and ecosystems. The boreal endemics and subendemics are found only in some habitats of the eastern part of Eurasia and the northwestern part of North America. However, they are often abundant and may dominate in local assemblages. In Eurasia, the local endemics occupy different open habitats, from the mountain tundras to openings. The only Podismopsis silvestris is found in the spruce forest [15]. In North America, the local endemics investigated are associated with the mountains steppes [28].

\section{The Boreal Orthoptera: Retrospective and Prospective}

As one knows, reconstruction of the past of many taxa faces numerous problems. The most important of them is the shortage of their fossils. This results in development of different hypotheses explaining biogeographic and ecological history of such groups. In the absence of adequate fossil data, an applicable approach may be based on a complex analysis of the limiting factors, adaptations to particular living conditions, and the optimum conditions, which may be evaluated based on the species range shape and the population distribution within the range $[6,41,42]$. A phylogeographic approach also allows us to reconstruct some important events and processes of the past [43-47]. However, these studies should develop on the basis of integration of historical geographic and genetic data [47].

The history of the boreal Orthoptera was discussed in a number of papers. Uvarov [48] noted that the orthopteran fauna of the northern Palaearctic area, especially in Europe, was seriously suffered during last glaciations. He also emphasized the role of "an enormous invasion of strange fauna swept over Europe from the East" (p. 1519). This group is associated with the eastern territory of temperate Asia. Uvarov suggested to call the group "the Angara fauna" and included in it the group Chorthippi (i.e., Chorthippus Fieb. and its relatives), the genera Podisma Berth., Melanoplus Stål, Stethophyma Fisch., Bryodema Fieb., Aeropus Gistl, Podismopsis Zub., and so forth. He also mentioned some relationships between the Angara fauna and the faunas of the southern parts of East Asia. Later Bey-Bienko [9] developed some Uvarov's idea concerning the Angara fauna of Orthoptera. He suggested to separate the so-called Siberian forest meadow group of Orthoptera associated with eastern part of Siberia. It includes at least Podismopsis poppiusi, Chorthippus fallax, and Ch. intermedius (B.-Bien.).

Lindroth [49] discussed different aspects of zoogeographic connections between Europe and North America 
and emphasized their relative weakness. He noted that more or less evident relationships may be for arctic and subarctic forms and some taxa at "a lower evolutionary stage." Lindroth also showed the extremely significant role of species invasions due to human activity from Eurasia to North America and vice versa. Lindroth [49] also discussed different hypotheses of earlier transatlantic land-connections. He noted that the continental drift took place too early to trace their biological consequences for the North Atlantic area.

Vickery [35] described some possible stages and ways of origination of the North American fauna of Orthoptera. He noted that the distribution of many Orthoptera taxa reflects very old, at least the Tertiary, connections between continents. However, other species, for example, Tetrix subulata and Melanoplus frigidus, could cross the Bering land bridge during the Quaternary period. He suggested that such grasshoppers might survive glaciations (especially the last one) in Beringia where some refugia with relatively mild and dry climate existed. Two endemics of the eastern part of the North American boreal zone look like to evolve (or survive) in small areas which were unglaciated.

Sergeev $[6,41]$ noted that the autochthonous component in the boreal zone of Eurasia is weak and associated with its eastern territories, which were unglaciated during the Quaternary period. Usually the autochthonous forms are close relatives of taxa connected with regions of East Asia where the broad-leaf forests, both temperate and subtropical, dominate. The widely distributed species usually inhabiting different meadows and steppes could spread over the boreal zone during glaciations when open habitats (tundras, tundra-steppes, and cold steppes) occupied huge territories in North Asia. Several species mainly associated with the nemoral zone of the Far East could distribute during interglacials and the climatic optimum of the Holocene $[6,9,41]$. Beside that, one should note that some data for beetles show that spreading rates of terrestrial insects during glacial-interglacials changes might be enough for their wide distribution [50]. This means that the main events determining the modern character of the boreal fauna could take place during the Quaternary period.

Thus, in the boreal zone, grasshoppers and their kin represent groups of different origins.

(1) The main part of genera is evidently associated with the southward areas of each continent. Their species can be usually interpreted as more or less recent invaders in the boreal zone, especially in North America. This group also includes the genera widely distributed in both the New and Old World (Conocephalus Thnb., Gryllus L., Tetrix Latr.).

(2) Another group of the genera is associated with the Holarctic Region. These Orthoptera are often cold resistant. They could distribute over the boreal zone from the end of the Neogene. However, the molecular phylogenetic analysis [51] showed that the dispersion time of some taxa from Eurasia to North America (e.g., the ancestors of the North American Stethophyma) could be considerably earlier than the estimations published [35]. The interchanges between Eurasia and North America could take place many times across the Bering land bridge. Several related genera (e.g., Bruneria McNeil-Stenobothrus Fisch.) demonstrate relatively old connections (probably, associated with first glaciations), on the contrary, two species distributed in North America and Eurasia (Tetrix subulata, Melanoplus frigidus) could cross this bridge during the last glaciations.

The boreal endemics of Eurasia and North America look like quite different. The first group consists from the species associated with territories not covered by ice sheets during the Quaternary period. Although they are ecologically diverse and prefer various types of habitats (from mountain tundras to openings and meadows), the nemoral origin of almost all of them is evident. The differentiation of possible ancestral forms could be resulted from separation of different types of the forest landscapes (especially the boreal ones) in the end of the Neogene. However, the evolution of the several species of the genus Prumna Motsch. might be determined by the significant level of isolation of local populations and by limited dispersal opportunities.

The local endemic of North America can be divided into two pairs. Origin of both can be explained by the refugium distribution during the last glaciations. One pair includes species associated with the north-western part of the continent. The evolution of both forms could take place in the Beringian refugia [35]. This hypothesis is supported by data concerning fossil beetles [52]. Two species of the genus Melanoplus were evidently evolved during the last glaciations when the areas of their origination remained off ice sheets [35].

Hence the distribution patterns of the boreal Orthoptera show that one can estimate the number of stages and sequence of their evolution and interchanges, but do not allow us to determine the exact periods of these processes and the directions of interchanges between two continents. For instance, the main migration direction of Melanoplus frigidus is still debatable [35, 44]. However, last comparative studies of molecular phylogeny of melanopline grasshoppers showed that the main direction dispersal could be from South America to Eurasia [45].

One of the principal results of retrospective views on faunas and populations is the opportunity to forecast their possible changes in the future. If the trend of global warming will hold, the boreal zone will shift northwards and its area will reduce $[53,54]$; however, the precipitation will decrease [54]. This should result in the Orthoptera distribution pattern. Grasshoppers occupying the boreal zone will shift the northern boundaries of their ranges northwards, up to Arctic Ocean. Local endemics may be eliminated due to high rates of changes. This is especially important for the high montane forms occurred above timberline, because their native landscapes will disappear. Abundance and diversity of other boreal grasshoppers with isolated populations in mountains and on plain openings and meadows will potentially decrease down to their full elimination [55]. On the contrary, some widely distributed species associated with the steppe and forest steppe life zones will be able to spread northwards along different anthropogenic habitats, such as clearings, roadsides, agricultural fields, and pastures [41]. Besides, their abundance may increase and some of them may become potential pests. 


\section{Acknowledgments}

The author benefited from interactions with A. Latchininsky and anonymous reviewers. He wishes to express his sincere thanks to the Russian Federal Programme "Scientific and Scientific-Pedagogical Staff of Innovative Russia" (project no. 02.740.11.0277) and the Programme of the Federal Agency for Education "Development of Research Potentials for Higher Education” (Grant no. 1577) for vital financial support.

\section{References}

[1] L. Hamet-Ahti, "The boreal zone and its biotic subdivision," Fennia, vol. 159, no. 1, pp. 69-75, 1981.

[2] A. G. Isachenko, Landshafty SSSR, Leningrad University, Leningrad, Russia, 1985.

[3] V. E. Elton, The Ecology of North America, University of Illinois Press, Urbana, IL, USA, 1963.

[4] C. H. Merriam, "Results of a biological survey of the San Francisco Mountain Region and desert of the Little Colorado in Arizona," North American Fauna, vol. 3, pp. 1-136, 1890.

[5] A. F. Emeljanov, "Predlozheniya po klassifikacii i nomenclature arealov," Entomologicheskoie Obozrenie, vol. 53, no. 3, pp. 497-522, 1974 (Russian).

[6] M. G. Sergeev, Zakonomernosti Rasprostraneniya Pryamokrylyh Nasekomyh $v$ Severnoj Asii, Nauka, Novosibirsk, Russia, 1986.

[7] M. G. Sergeev, "Distribution patterns of Orthoptera in North and Central Asia," Journal of Orthoptera Research, vol. 1, pp. 14-24, 1992.

[8] M. G. Sergeev, "The general distribution of Orthoptera in the main zoogeographical regions of North and Central Asia," Acta Zoologica Cracoviensia, vol. 36, no. 1, pp. 53-76, 1993.

[9] G. Ya. Bey-Bienko, "Priamokrylye-Orthoptera and kozhistokrylye-Dermaptera," in Zhivotnyi mir SSSR. T. 4. Lesnaja zona, pp. 527-552, USSR Academy of Sciences, Moscow and Leningrad, Russia, 1953.

[10] V. R. Vickery, "The Orthoptera of Alaska, Yukon, and the Mackenzie District of the Northwest Territories," Transactions of the American Entomological Society, vol. 93, no. 3, pp. 249278, 1967.

[11] D. Otte, The North American grasshoppers. Vol. I. Acrididae: Gomphocerinae and Acridinae, Harvard University Press, Cambridge, MA, USA and London, UK, 1981.

[12] G. Daviddowitz and M. L. Rosenzweig, "The latitudinal gradient of species diversity among North American grasshoppers (Acrididae) within a single habitat: a test of the spatial heterogeneity hypothesis," Journal of Biogeography, vol. 25, no. 3, pp. 553-560, 1998.

[13] B. P. Uvarov, Grasshoppers and Locusts. Vol. 2, Centre for Overseas Pest Research, London, UK, 1977.

[14] M. E. Chernyakhovskiy, "Zametki o faune i ecologii priamokrylyh nasekomyh Pechoro-Ilychskogo zapovednika," in Trudy Pechoro-Ilychskogo Zapovednika, vol. 14, pp. 126-128, 2005.

[15] S. Yu. Storozhenko, "Fauna i naselenie priamokrylych nasekomyh (Orthoptera) ostrova Sakhalin," in Pauki i Nasekomye Dal'nego Vostoka SSSR, A. B. Egorov, Ed., pp. 19-30, Vladivostok, Russia, 1981.

[16] V. R. Vickery, "Orthopteroid insects (Orthoptera) of the Yukon," in Insects of the Yukon, H. V. Danks and J. A. Downes,
Eds., pp. 223-239, Biological Survey of Canada (Terrestrial Arthropods), Ottawa, Canada, 1997.

[17] L. S. Zimin, Kubyshki Saranchovyh. Morphologiya, Systematika, Diagnostika I Ekologiya, USSR Academy of Sciences, Moscow and Leningrad, Russia, 1938.

[18] A. Albrecht, "Utbredningen av rätvingar, kackerlackor och tvestjärtar i Östra Fennoskandien (Orthoptera, Blattodea, Dermaptera)," Notulae Entomologicae, vol. 59, no. 2, pp. 5364, 1979.

[19] D. Otte, The North American Grasshoppers. Vol. II. Acrididae: Oedipodinae, Harvard University Press, Cambridge, MA, USA and London, UK, 1984.

[20] J. L. Capinera, R. D. Scott, and T. J. Walker, Field Guide to Grasshoppers, Katydids, and Crickets of the United States, Cornell University Press, Ithaca, NY, USA and London, UK, 2004.

[21] G. F. Gause, "Studies on the ecology of the Orthoptera," Ecology, vol. 11, no. 2, pp. 307-325, 1930.

[22] G. Ya. Bey-Bienko, "K voprosu o zonal'no-ecologicheskom raspredelenii saranchevyh (Orthoptera, Acrididae) v Zapadno-Sibirskoy i Zaisanskoi nizmennostiah," Trudy po Zastshite Rasteniy, Seriya Entomologicheskaya, vol. 1, no. 1, pp. 51-90, 1930 (Russian).

[23] M. E. Chernyakhovskiy, "Saranchovye basseyna Podkamennoi Tunguski (Vostochnaya Sibir) i cherty ih ekologii," in Fauna $i$ Ecologia Zhivotnyh, pp. 17-25, Moscow, Russia, 1972.

[24] M. E. Chernyakhovskiy, "Gruppirovki saranchovyh Tomsow oblasti," in Fauna i Ecologia Bespozvonochnyh Zhivotnyh, pp. 176-184, Moscow, Russia, 1976.

[25] M. E. Chernyakhovskiy, "Raspredelenie priamokrylyh nasekomyh (Orthoptera) v biocenozah Severnogo Urala," in Principy i Sposoby Sohraneniya Bioraznoobraziya, pp. 149-151, Yoshkar-Ola, Russia, 2006.

[26] R. I. Karelina, "K faune priamokrylyh (Orthoptera) Yuzhnoj Yakutii," Trudy Vesoyuznogo Entomologicheskogo Obstshestva, vol. 57, pp. 112-122, 1974 (Russian).

[27] D. I. Berman and V. G. Mordkovich, "Entomologicheskie osobennosti pripolarnyh stepey Yakutii," Biuletten Moskovskogo Obstshestva Ispytateley Prirody. Biologiya, vol. 84, no. 1, pp. 39-45, 1979 (Russian).

[28] D. I. Berman, S. Yu. Storozhenko, and S. K. Kholin, "To the fauna and bionomic of grasshoppers (Orthoptera: Acrididae) of the southern Yukon, Canada," Far Eastern Entomologist, no. 23, pp. 1-8, 1995.

[29] E. Miram, "Beitrag zur Kenntnis der Orthoptrenfauna der nördlichen Polarzone mit Berücksichtigung der Dermapteren und Blattodeen," Zoologischer Anzeiger, vol. 97, no. 1-2, pp. 37-46, 1931.

[30] N. A. Weber, "A survey of the insects and related arthropods of Arctic Alaska. Part 1," Transactions of the American Entomological Society, vol. 76, pp. 147-206, 1950.

[31] K. Harz, Die Orthopteren Europas. The Orthoptera of Europe. Vol. II, Dr. W. Junk B.V., The Hague, The Netherlands, 1975.

[32] J. Gosálvez, C. López-Fernández, and E. Morales Agacino, "Algunas consideraciones sobre el papel que como organísmo indicador del estado de ciertos prados de alta montaña juega el Melanoplus frigidus strandi (Fruhst.) (Orthoptera). Acrídido nuevo para la fauna ibérica," Miscellanea Zoologica, vol. 6, pp. 41-44, 1980.

[33] D. C. McE. Kevan, "Orthoptera (s. str.)," Memoirs of the Entomological Society of Canada, vol. 111, no. 108, pp. 321323, 1979.

[34] V. R. Vickery and D. C. McE. Kevan, "A monograph of the orthopteroid insects of Canada and adjacent regions," 
Memoirs of the Lyman Entomological Museum and Research Laboratory, vol. 13, no. 1, pp. 1-679, 1983.

[35] V. R. Vickery, "The northern Nearctic Orthoptera: their origin and survival," in Evolutionary Biology of Orthopteroid Insects, B. Bacetti, Ed., pp. 581-591, Ellis Horwood, Chichester, UK, 1987.

[36] M. A. Glazovskaya, Pochvy Zarubezhnyh Stran, Vyshshaya Shkola, Moscow, Russia, 1983.

[37] P. U. Clark, A. S. Dyke, J. D. Shakun et al., "The last glacial maximum," Science, vol. 325, no. 5941, pp. 710-714, 2009.

[38] A. V. Latchininsky, "Grasshopper problems in Yakutia (Eastern Siberia, Russia) grasslands," Journal of Orthoptera Research, vol. 4, pp. 29-34, 1995.

[39] M. G. Sergeev, "Ecogeographical distribution of Orthoptera," in The Bionomics of Grasshoppers, Katydids and Their Kin, S. K. Gangwere et al., Ed., pp. 129-146, CAB International, Oxon, UK and New York, NY, USA, 1997.

[40] M. G. Sergeev, "Soobstshestva saranchovyh (Orthoptera, Acrididae) preriy Velikih Ravnin. I. Landshafnye type," Evroaziatskiy Entomologicheskiy Zhurnal, vol. 3, no. 1, pp. 1-9, 2004 (Russian).

[41] M. G. Sergeev, "Opyt actualisticheskoy rekonstrukcii stanovleniya faun i soobstshestv pryamokrylyh (Orthoptera) vnetropicheskoi Azii," Trudy Russkogo Entomologicheskogo Obstshestva, vol. 80, no. 1, pp. 41-60, 2009 (Russian).

[42] M. G. Sergeev, "Concepts of classic and modern biogeography: contribution of Russian entomologists," Entomological Review, vol. 90, no. 3, pp. 311-332, 2010.

[43] J. C. Avise, "The history and purview of phylogeography: a personal reflection," Molecular Ecology, vol. 7, no. 4, pp. 371379, 1998.

[44] G. Litzenberger and W. Chapco, "A molecular phylogeographic perspective on a fifty-year-old taxonomic issue in grasshopper systematics," Heredity, vol. 86, no. 1, pp. 54-59, 2001.

[45] C. Amédégnato, W. Chapco, and G. Litzenberger, "Out of South America? Additional evidence for a southern origin of melanopline grasshoppers," Molecular Phylogenetics and Evolution, vol. 29, no. 1, pp. 115-119, 2003.

[46] O. N. Guliaeva, L. V. Vysotskaya, and M. G. Sergeev, "Taksonomicheskie i filogeneticheskie otnosheniya saranchovyh (Orthoptera, Acrididae) Golarktiki: novyj vzglyad na starye problemy," Euroasian Entomological Journal, vol. 4, no. 2, pp. 87-94, 2005 (Russian).

[47] C. L. Richards, B. C. Carstens, and L. L. Knowles, "Distribution modelling and statistical phylogeography: an integrative framework for generating and testing alternative biogeographical hypotheses," Journal of Biogeography, vol. 34, no. 11, pp. 1833-1845, 2007.

[48] B. P. Uvarov, "Composition and origin of the Palaearctic fauna of Orthoptera," in Proceedings of the 5th International Congress of Zoology, pp. 1516-1524, Budapest, Hungary, 1929.

[49] C. H. Lindroth, The Faunal Connections between Europe and North America, John Wiley \& Sons, New York, NY, USA, and Almqvist \& Wiksell, Stockholm, 1957.

[50] G. R. Coope, "Mid-Weichselian climatic changes in Western Europe, re-interpreted from coleopteran assemblages," in Quaternary Studies, R. P. Suggate and M. M. Cresswell, Eds., pp. 101-108, The Royal Society of New Zealand, Wellington, New Zealand, 1975.

[51] M. Fries, W. Chapco, and D. Contreras, "A molecular phylogenetic analysis of the Oedipodinae and their intercontinental relationships," Journal of Orthoptera Research, vol. 16, no. 2, pp. 115-125, 2007.
[52] S. A. Elias, "Climatic tolerances and zoogeography of the late pleistocenebeetle Fauna of Beringia," Geographie Physique et Quaternaire, vol. 54, no. 2, pp. 143-155, 2000.

[53] N. N. Vygodskaya, P. Y. Groisman, N. M. Tchebakova et al., "Ecosystems and climate interactions in the boreal zone of northern Eurasia," Environmental Research Letters, vol. 2, no. 4, Article ID 045033, 7 pages, 2007.

[54] R. A. Monserud, O. V. Denissenko, and N. M. Tchebakova, "Comparison of Siberian paleovegetation to current and future vegetation under climate change," Climate Research, vol. 3, no. 3, pp. 143-159, 1993.

[55] M. G. Sergeev, "Conservation of orthopteran biological diversity relative to landscape change in temperate Eurasia," Journal of Insect Conservation, vol. 2, no. 3-4, pp. 247-252, 1998. 

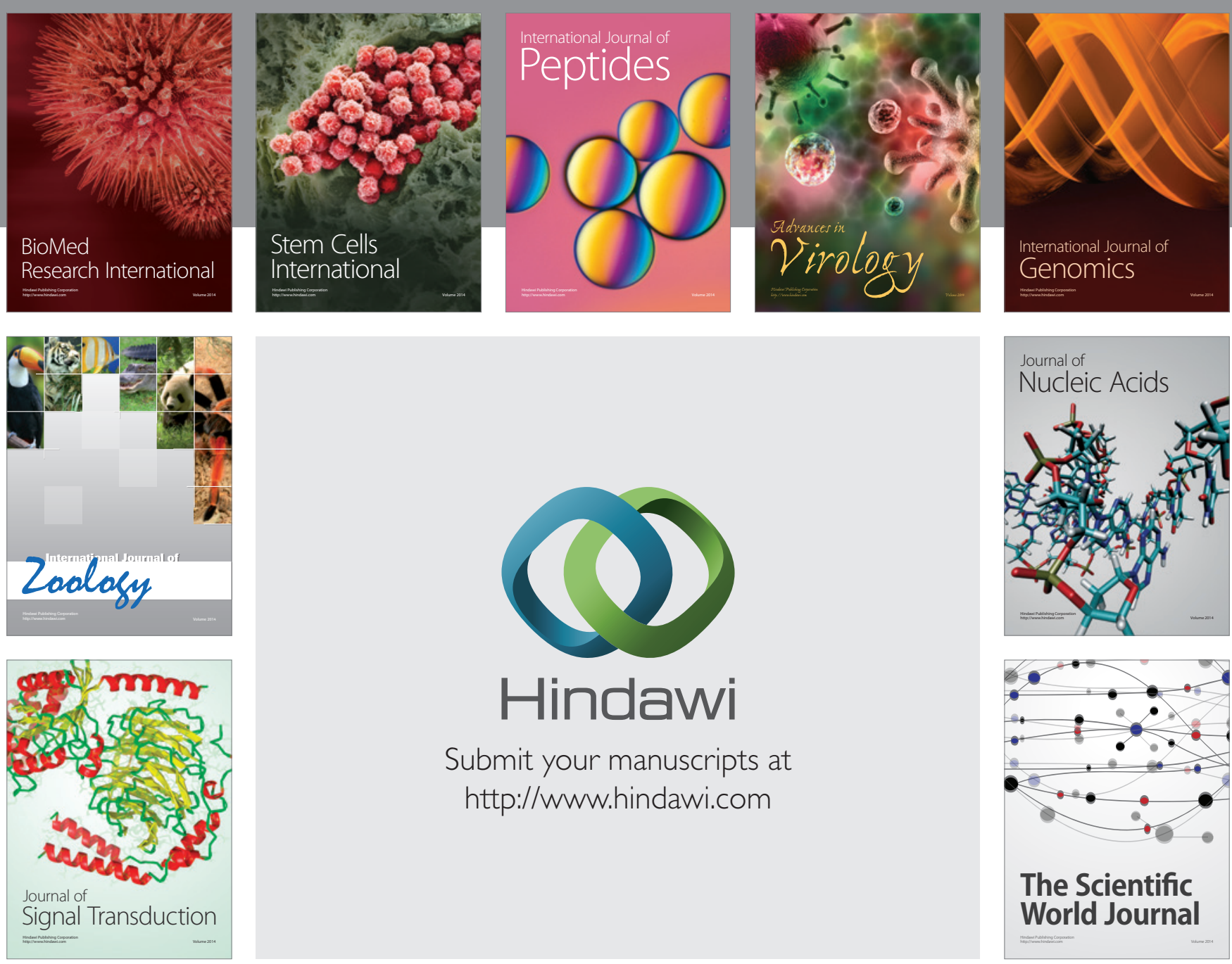

Submit your manuscripts at

http://www.hindawi.com
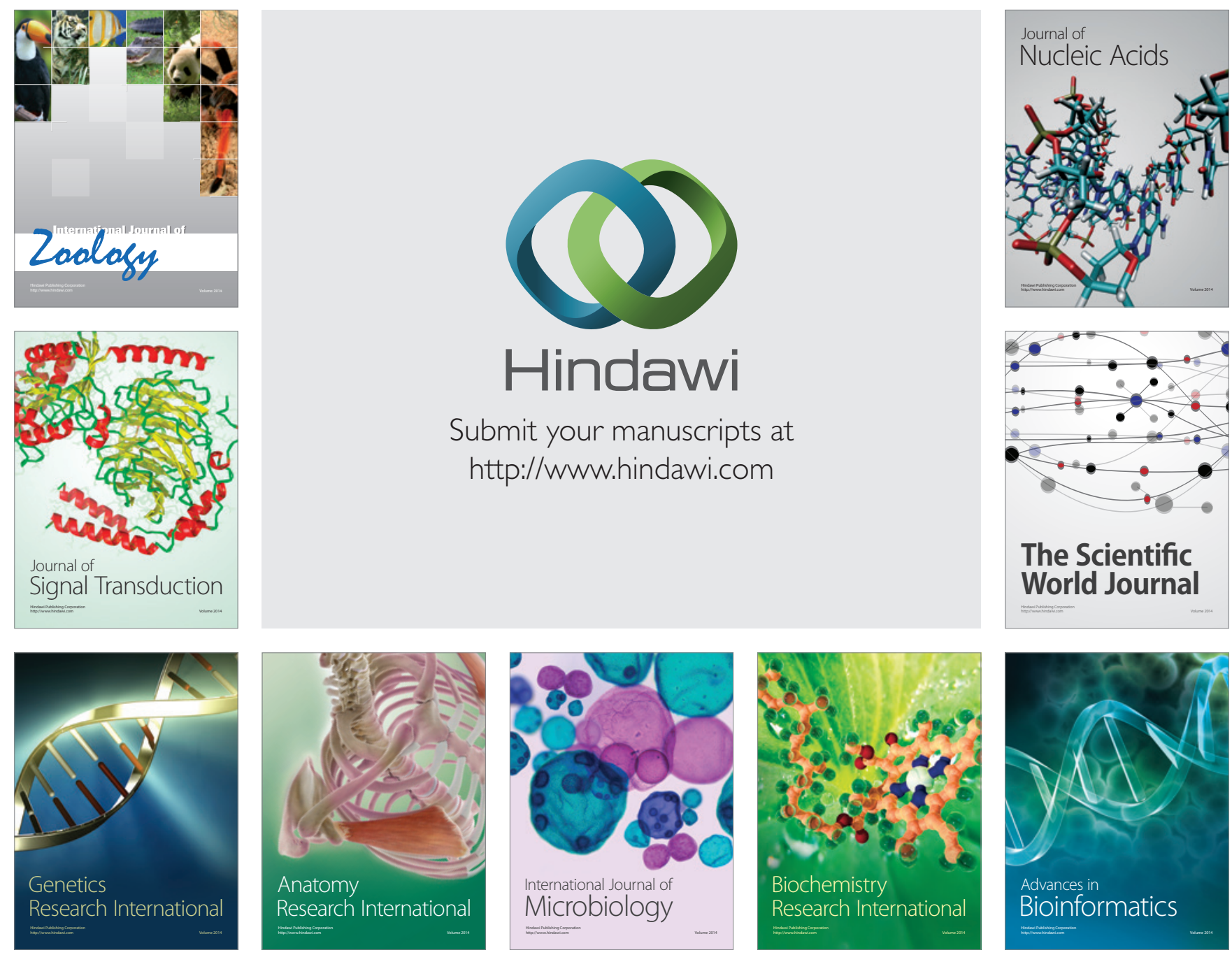

The Scientific World Journal
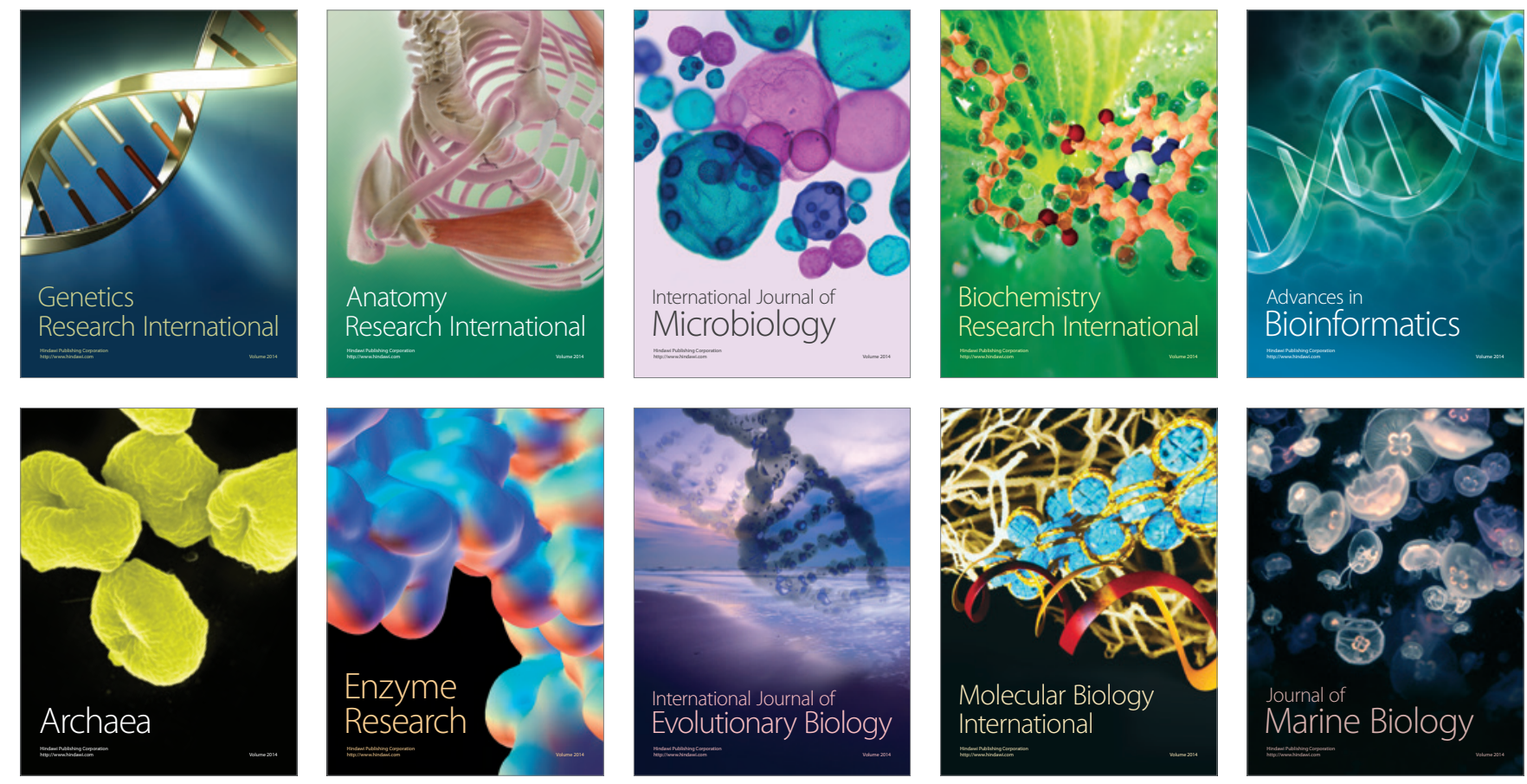